\title{
Innovation and Technology Dissemination in Clean Technology Markets and the Developing World: The Role of Trade, Intellectual Property Rights, and Uncertainty
}

\section{Kristina M. Lybecker}

\begin{abstract}
Innovation is an inherently risky and uncertain process. Many of the broader challenges to innovation in general are both mirrored and exaggerated in clean technology innovation. The development of environmental technologies is further complicated by the public goods nature of knowledge, environmental externalities, and uncertainty. This study on clean technology focuses on recent work on the role of uncertainty, the participation of emerging and developing nations, the controversy surrounding intellectual property rights, and the variety of market actors and strategies in place. The paper also considers the policy instruments that are available, the cost, benefits and consequences of their use. As scholars continue to analyze when, where, why and how clean technology innovations are developed and adopted, it is essential that government policymakers aim to reduce uncertainty and risk, incentivize innovation with effective intellectual property rights, and foster transparency in the market. This continues to be a field of increasing future importance, and a rich area for continued academic study and analysis. Consumers, government policymakers and innovators would all benefit from a greater understanding of the process of technological change in the development, diffusion and financing of clean technologies.

Keywords: clean technology, environmental innovation, innovation policy, barriers to innovation, developing countries.
\end{abstract}

\section{INTRODUCTION}

Innovation is an inherently risky and uncertain process. Many of the broader challenges to innovation in general are both mirrored and exaggerated in clean

\footnotetext{
* Kristina M. Lybecker, Ph.D., Associate Professor of Economics and Business at Colorado College, 14 E. Cache la Poudre Street, Colorado Springs, Colorado 80903, Kristina.Lybecker@ColoradoCollege.edu.
} 
technology innovation. ${ }^{1}$ The four primary challenges for such innovation are externalities, uncertainty, asymmetric information, and market power. Clean technology is characterized by two market failures: the public goods nature of knowledge and environmental externalities. In addition, uncertainty regarding the qualities of the innovation, as well as future prices of inputs and substitutes will complicate the development and adoption processes. Ultimately, uncertainty and changing regulations may both encourage and inhibit clean technology innovation, providing policymakers with a critical and challenging role in the process.

Innovation is best encouraged with market forces and incentives. However, in the case of environmental technologies, the presence of dual externalities inhibits the innovative process (Hall and Helmers, 2010). The combination of knowledge spillovers from research and development efforts and the public goods nature of these technologies provide a clear case for government intervention and policy (Popp, Newell and Jaffe, 2009; Hall and Helmers, 2010; Popp, 2010; Popp, 2012). Without effective public policy, markets alone are not likely to provide sufficient incentives for the development of clean technology innovations. Markets for new technologies are frequently characterized by uncertainty surrounding adoption, the impact on markets for competing and complementary products, application of the existing legal system, enforcement of intellectual property rights, and acceptance in international markets (Groba and Breitschopf, 2013; Kalamova, Johnstone and Haščič, 2013; Hall and Helmers, 2010; Popp, 2010; Heal, 2009). Innovative industries would benefit from greater predictability in each of these areas (Popp, Newell and Jaffe, 2009; Johnson and Lybecker, 2009a, 2009b, 2009c, Popp, 2010).

The market for clean technologies is characterized by significant uncertainties and risks, making the transfer of environmental technologies particularly difficult. As described here this is especially true for developing nations and presents distinct challenges for their adoption of clean technology innovation. While market forces and market failures shape the environmental

\footnotetext{
1 In the context of this study, the terms "environmental technology", "green technology" and "clean technology" are all used interchangeably. Admittedly there are differences between them, though this author could not find consistent, agreed upon definitions that clarify the subtle distinctions between the terms. Given that this is a literature review that draws upon (and quotes) the work of numerous other authors who each elect to use different terminologies, each of the terms appears in this paper. While it is regrettable that more precise language is not used here, it is because the studies discussed do not use more uniform language as it could not be applied. The U.S. Environmental Protection Agency (EPA) defines "environmental technology" as follows: "Environmental technology is an all-inclusive term used to describe pollution control devices and systems, waste treatment processes and storage facilities, and site remediation technologies and their components that may be utilized to remove pollutants or contaminants from or prevent them from entering the environment. Environmental technology is utilized in many configurations and is applied to many environmental problems, including devices and systems used in environmental programs to duplicate environmental conditions for test purposes or to control, prevent, treat, or remediate waste in process discharges (e.g., emissions, effluents) or the ambient environment. Usually, this term will apply to hardware-based systems; however, it can also apply to general methods or techniques used for pollution prevention, source reduction, or containment of contamination to prevent further movement of the contaminants." (U.S. EPA, 2014, http://www.epa.gov/quality/envtech.html).
} 
technology sector, political and cultural forces further complicate every aspect. In particular, it is important to recognize the role of regulation in the development of environmental innovation. As described in a review of earlier literature, environmental regulation may result in cost-saving innovation if a) the fixed costs of innovation are lower than compliance plus production, or b) spillover effects make innovation strategically a bad idea for the firm but a good idea for the society, or c) regulation helps to fix incentive problems between managers and owners, or d) regulation helps to clear information flow (Johnson and Lybecker, 2009a). Nonetheless, a number of clear conclusions can be drawn, as outlined above and discussed in further detail below.

This paper summarizes some of the key results from an updated literature review that tracks and further builds upon three 2009 literature reviews on clean technologies (Johnson and Lybecker, 2009a, 2009b, 2009c). The earlier studies examined the challenges surrounding three aspects of clean technology: its development, dissemination and financing. As in this review, they looked at technology innovation, transfer, and use, and in doing so also considered the types of factors that determine a country's success in creating a national system of innovation and technology dissemination. This new literature review builds upon those papers, focusing on the most recent contributions to the literature. ${ }^{2}$ The following sections focus on enabling environmental innovation, technology dissemination and use, the role of intellectual property rights, and the specific challenges facing developing countries. The paper concludes with a description of key findings and a discussion of the importance of balance in environmental policymaking.

\section{ENABLING ENVIRONMENTAL INNOVATION, TECHNOLOGY DISSEMINATION, AND USE}

Spending on research and development (R\&D) by the U.S. government in the energy sector continues to be relatively small, when compared to other industries and sectors, though it has increased in recent years. Given this, private investment is and will continue to be critical to funding the research and development that results in environmental innovations. Figure 1 plots nondefense research and development spending for the United States, 1953-2013. While the experience of the United States is not universal, it is illustrative since the United States is the source of the greatest share of these innovations. The American Association for the Advancement of Science reports that in 2012 the United States spent $\$ 4.36$ billion on non-defense energy research, double the amount from a decade ago. While energy has

2 Given that this paper aims to update the collection of three 2009 literature reviews, the focus is primarily on papers written since 2009 in the fields of economics and innovation. 
been the fastest-growing category of research and development spending, when adjusted for inflation, it continues to comprise a much smaller portion of the federal budget than health or space research (Plumer, 2013). In addition, since fossil fuels receive close to one-quarter of the federal funding it is perhaps not surprising that there is a dearth of research on funding for clean technology innovation.

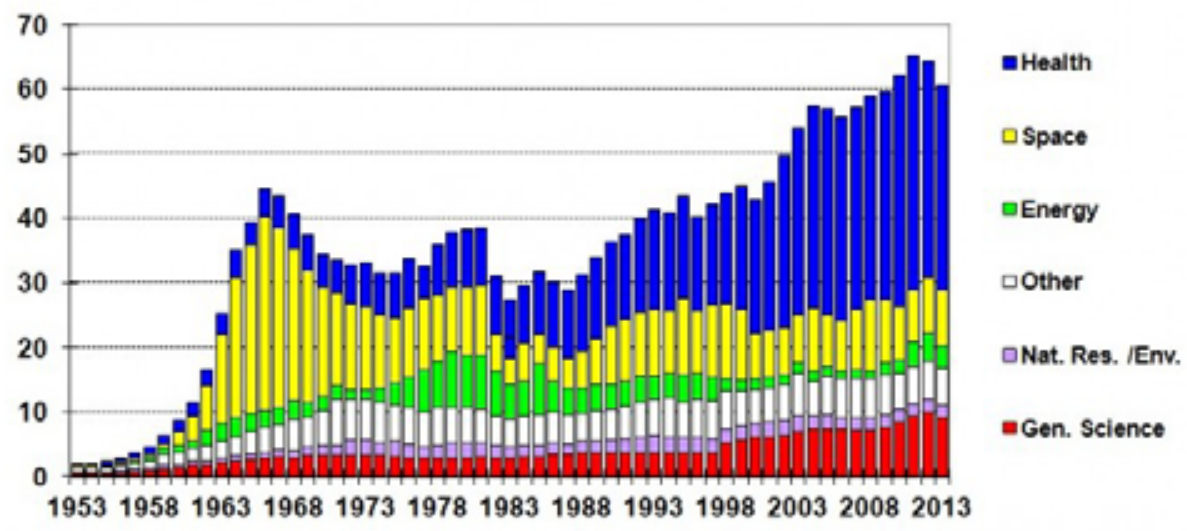

Figure 1. Federal R\&D Outlays for the United States, billions of USD Source: Plumer (2013).

Environmental innovation is characterized by dual externalities: (1) private underinvestment in research and development (R\&D) due to knowledge spillovers and (2) environmental externalities. ${ }^{3}$ While each externality presents significant challenges, the two externalities interact which compounds the problem. Moreover, both externalities operate on a global scale, further complicating the issues of regulation, mitigation and cooperation.

In both the development and the diffusion of environmental technology, the challenges surrounding uncertainty loom large. From beginning to end environmental innovation is characterized by uncertainty: uncertainty about

3 The dual externalities that characterize environmental innovation are beautifully described by Hall and Helmers (2010). "First, environmental pollution is a textbook example of an activity producing a negative externality, i.e., 'an unintended consequence of market decisions which affect individuals other than the decision maker' as the social costs associated with pollution exceed private costs. Second, knowledge required for the development of (green) technologies is characterized by non-excludability, i.e., other actors cannot be excluded from accessing and using the knowledge produced by the original source and non-rivalry or non-exhaustibility of knowledge, i.e., if one actor uses some specific knowledge, the value of its use is not reduced by other actors' also using it. Due to these characteristics, 'firms can acquire information created by others without paying for that information in a market transaction, and the creators (or current owners) of the information have no effective recourse, under prevailing laws, if other firms utilize information so acquired'. In this sense, incomplete appropriability of knowledge represents an externality and thus leads to a gap between private and social returns to innovation." (Hall and Helmers, 2010, p.4). 
actual costs, uncertainty about the end-product of a research process, uncertainty about the reception by the market, uncertainty about the ability to appropriate the returns to research while competitors try to produce similar results, uncertainty about current and future policies and regulations, uncertainty surrounding the pricing of competing as well as complementary goods, and uncertainty about regulatory impacts on the research process and end-result. This is exacerbated by the uncertainty surrounding the rate of innovation itself which complicates any estimate of global climate change, making it difficult to substantiate the reasons that justify further research funding. One of the key challenges, therefore, is for governments to reduce such uncertainties and create a stable and predictable regulatory and market environment that enhances innovation, and the development, diffusion and dissemination of technology.

Technological innovations are of minimal value if the society fails to adopt them and make use of them. As noted by Popp, Newell and Jaffe (2010), little scholarship has focused specifically on the international transfer of environmental technologies and that gap in the literature remains today. However, beyond the transfer of these technologies, diffusion and adoption are paramount to the ultimate usefulness of a new technology. It is not uncommon for a superior technology (in terms of performance and/or cost) to reach the market and fail to be widely adopted. Accordingly, it is important to examine the forces that contribute to the dissemination of technology.

Beyond the issues surrounding market and behavioral failures there are other factors that both facilitate and inhibit the diffusion of environmental technologies. While much work remains to be done in this area, existing work can illuminate some of the factors that matter to the diffusion and adoption of environmental technologies. Consider Table 1 below which provides a summary of the key research on the cost-effectiveness of past U.S. energyefficiency programs. Within the table, Popp, Newell and Jaffe (2010) identify the barriers to adoption as well as the key results from each paper. 
Table 1. Barriers to adoption of environmentally-friendly technologies

\begin{tabular}{|c|c|c|c|c|}
\hline Article & Technology & $\begin{array}{l}\text { Barrier(s) to } \\
\text { Adoption }\end{array}$ & Data & Key Results \\
\hline $\begin{array}{l}\text { Jaffe and Stavins } \\
\text { (1995) }\end{array}$ & $\begin{array}{l}\text { Thermal } \\
\text { insulation }\end{array}$ & $\begin{array}{l}\text { Up-front costs } \\
\text { matter more }\end{array}$ & $\begin{array}{l}\text { US residential } \\
\text { construction } \\
1979-88\end{array}$ & $\begin{array}{l}\text { Lower adoption costs } \\
3 x \text { more likely to } \\
\text { encourage adoption } \\
\text { than increased energy } \\
\text { costs }\end{array}$ \\
\hline $\begin{array}{l}\text { Hassett and Metcalf } \\
\text { (1995) }\end{array}$ & $\begin{array}{l}\text { Residential } \\
\text { energy } \\
\text { conservation }\end{array}$ & $\begin{array}{l}\text { Up-front costs } \\
\text { matter more }\end{array}$ & $\begin{array}{l}\text { US households } \\
1979-1981\end{array}$ & $\begin{array}{l}\text { Installation cost savings } \\
\text { via tax credits } \\
\text { encourage adoption }\end{array}$ \\
\hline $\begin{array}{l}\text { Kemp } \\
(1997)\end{array}$ & $\begin{array}{l}\text { Thermal } \\
\text { home } \\
\text { insulation }\end{array}$ & $\begin{array}{l}\text { Inadequate } \\
\text { information }\end{array}$ & $\begin{array}{l}\text { Netherlands } \\
\text { households }\end{array}$ & $\begin{array}{l}\text { Government subsidies } \\
\text { do not lead to adoption. } \\
\text { Epidemic model fits } \\
\text { data better than } \\
\text { rational choice model. }\end{array}$ \\
\hline $\begin{array}{l}\text { Metcalfe and Hassett } \\
\text { (1999) }\end{array}$ & $\begin{array}{l}\text { Attic } \\
\text { insulation }\end{array}$ & $\begin{array}{l}\text { Inadequate } \\
\text { information }\end{array}$ & $\begin{array}{l}\text { U.S. Residential } \\
\text { Energy } \\
\text { Consumption } \\
\text { Survey, } \\
1984,1987, \\
\& 1990\end{array}$ & $\begin{array}{l}\text { Actual energy savings } \\
\text { are less than promised }\end{array}$ \\
\hline $\begin{array}{l}\text { Reppelin-Hill } \\
\text { (1999) }\end{array}$ & $\begin{array}{l}\text { Clean steal } \\
\text { technologies }\end{array}$ & Import barriers & $\begin{array}{l}\text { Adoption of } \\
\text { electric arc } \\
\text { furnace } \\
\text { in } 30 \text { countries, } \\
1970-1994\end{array}$ & $\begin{array}{l}\text { Import barriers restrain } \\
\text { the adoption from } \\
\text { foreign-produced goods }\end{array}$ \\
\hline $\begin{array}{l}\text { Howarth et al. } \\
(2000)\end{array}$ & $\begin{array}{l}\text { Energy-saving } \\
\text { technology } \\
\text { (efficient } \\
\text { lighting } \\
\text { equipment) }\end{array}$ & $\begin{array}{l}\text { Agency decision } \\
\text { making problems, } \\
\text { Inadequate } \\
\text { information }\end{array}$ & $\begin{array}{l}\text { Green Lights } \\
\text { and Energy } \\
\text { Star programs }\end{array}$ & $\begin{array}{l}\text { Voluntary programs } \\
\text { lead to wider adoption } \\
\text { in private firms. } \\
\text { Inadequate information } \\
\text { inhibits adoption. }\end{array}$ \\
\hline $\begin{array}{l}\text { Nijkamp et al. } \\
\text { (2001) }\end{array}$ & $\begin{array}{l}\text { Energy- } \\
\text { efficient } \\
\text { technology }\end{array}$ & $\begin{array}{l}\text { Economic barriers } \\
\text { - alternative } \\
\text { investment } \\
\text { - low energy } \\
\text { costs } \\
\text { - capital } \\
\text { replacement }\end{array}$ & $\begin{array}{l}\text { Survey of } \\
\text { Dutch firms }\end{array}$ & $\begin{array}{l}\text { Economic barriers affect } \\
\text { adoption more than } \\
\text { financial and } \\
\text { uncertainty barriers }\end{array}$ \\
\hline $\begin{array}{l}\text { Mulder et al. } \\
\text { (2003) }\end{array}$ & $\begin{array}{l}\text { Energy } \\
\text { efficiency } \\
\text { technologies }\end{array}$ & $\begin{array}{l}\text { Complementarities } \\
\text { among } \\
\text { technologies }\end{array}$ & $\mathrm{N} / \mathrm{A}$ & $\begin{array}{l}\text { Complementarities and } \\
\text { learning-by-doing } \\
\text { process impede } \\
\text { adoption }\end{array}$ \\
\hline $\begin{array}{l}\text { Anderson and Newell } \\
(2004)\end{array}$ & $\begin{array}{l}\text { Firm-level } \\
\text { adoption of } \\
\text { energy-saving } \\
\text { projects } \\
\text { recommended } \\
\text { by energy } \\
\text { audits }\end{array}$ & $\begin{array}{l}\text { Inadequate } \\
\text { information on } \\
\text { technologies, } \\
\text { Initial costs and } \\
\text { payback years } \\
\text { of adoption }\end{array}$ & $\begin{array}{l}\text { U.S. Department } \\
\text { of Energy's } \\
\text { Industrial } \\
\text { Assessment } \\
\text { Centers } \\
\text { database, } \\
1981-2000\end{array}$ & $\begin{array}{l}\text { Firms adopt additional } \\
\text { projects with improved } \\
\text { information. Up-front } \\
\text { costs have } 40 \% \text { greater } \\
\text { effect than energy costs. }\end{array}$ \\
\hline
\end{tabular}

Source: Popp, Newell and Jaffe (2010, p.70). 
It is important to recognize that the dissemination of technology may depend on achieving an efficient scale of production, so as to reduce perunit production costs and facilitate adoption. Given that a majority of environmental innovations are subject to economies of scale or increasing returns to scale, greater levels of output will generate lower per-unit costs which may indicate that larger firms are better able to both develop and deliver environmental technologies. "This benefit associated with the overall scale of technology adoption has sometimes been referred to as 'dynamic increasing returns,' which may be generated by learning-by-using, learning-bydoing, or network externalities. Thus, just like the creation of the technology itself, information about the performance of a technology has an important public goods component." (Popp, Newell and Jaffe, 2010, p.4) Accordingly, Popp, Newell and Jaffe note that the value of an innovation to one individual/ firm may be dependent on the number of other users who have adopted the innovation (Popp, Newell and Jaffe, 2010). Across countries and technologies, in the presence of economies of scale, users will benefit from an increasing number of other users.

Henderson and Newell (2010) explore the history of innovation in several industries that may hold lessons for the energy industry. They focus on industries that have experienced extraordinary rates of technological progress and draw out four themes believed to be particularly important to energy innovation. These are: sustained federal support for fundamental research over a long period of time; effective governance balancing public and private funding such that private resources are not crowded out; welldesigned institutional mechanisms for effective technology transfer; and the critical importance of public funding for training the scientific and technical personnel who become the backbone of an innovation private sector. The importance of public funding is striking given the relatively low levels of existing funding. That is, "publicly funded energy research constitutes about 3 percent of the total federal R\&D budget or less than 0.03 percent of gross domestic product." (Henderson and Newell, 2010, p.5) Notably energy R\&D budgets have risen most recently and were dramatically increased under the American Recovery and Reinvestment Act which added \$14 billion in spending in 2009. In a description of the importance of slow and steady growth in R\&D budgets, Popp (2010) describes the experience of the U.S. National Institutes of Health (NIH), as analyzed by Freeman and van Reenen (2009). The studies draw striking parallels between the fields of medicine and energy, focusing on the importance of allowing time for the development of young talent in the field.

Any analysis of the development and dissemination of environmental technologies is complicated by the variety of market entities involved in 
environmental innovation: commercial and industrial firms, government organizations, academic institutions, non-governmental organizations, as well as combinations of all of these agents through partnerships and joint ventures. Their roles both support and complement the activities of traditional market actors. Research coordination agreements remedy market failures in the development and diffusion of environmental innovation, preventing duplicative R\&D efforts. Partnerships and joint ventures allow clean technology firms to increase their presence in developing country markets.

Numerous studies conclude that an unambiguous ranking of policy instruments is not possible given the variety of factors that play into their valuation: the policymakers' preferences, perceived costs of environmental externalities, the innovator's ability to appropriate knowledge spillover benefits, and the state of technology, among others (Popp 2010, Borenstein 2011).

As previous studies have frequently concluded (Johnson, Lybecker, 2009c), the literature on financing environmental innovation is very limited and has little to offer in terms of the benefits of private versus public funding or the merits of one financing mechanism over another. The most effective mechanism will undoubtedly depend on the type of technology, the maturity of the market, competing technologies, the lifecycle stage of the technology, and the risk and uncertainty surrounding the development process. In this vein, Stewart, Kingsbury and Rudyk (2009) point to the need for a variety of new arrangements to generate public and private financing for climate technologies since there is no one-size-fits-all solution. Ultimately the best case scenario would encourage financing and remove barriers to entry while allowing the wisdom of the market to prevail and guide investment choices.

\section{The Role of Intellectual Property Rights}

A majority of economists agree that strong intellectual property rights are an essential prerequisite to the development of environmental technologies (Hall, 2014; U.S. Chamber of Commerce, 2013; Mansfield, 1986). Moreover, the majority of economic studies indicate that intellectual property rights are not a barrier to the transfer of technology to developing countries, though the concern remains a prominent theme in the literature (for a review of this literature, see Copenhagen Economics 2010). Although the value of patents, and other forms of protection, varies across countries, across industries and across innovations, numerous studies have documented the reasons to encourage strong patent law (Moser 2013, Copenhagen Economics 2010, Hall and Helmers 2010, Mansfield 1986, among many others). The majority 
of the studies examining environmental innovation focus on the effectiveness of patent protection rather than intellectual property rights in general or other forms such as trade secrets, trademarks, or copyrights. The other instruments are found to be much less important for technology transfer. While dissemination of environmental innovations is enhanced by stronger levels of patent protection, it is essential to acknowledge the necessity of complementary factors such as infrastructure, absorptive capacity, effective government policies and regulations, knowledge institutions, access to credit and venture capital, skilled human capital, and networks for research collaboration.

Theoretically the question of whether IPRs facilitate or inhibit technology transfer amounts to a trade-off between the potential of intellectual property rights enforcement raising the cost or limiting access to protected innovations against the potential for IPR protection to facilitate trade and foreign direct investment, which are themselves valuable means of technology transfer (Allan, Jaffe and Sin, 2014). However, rather than serve as a barrier there is evidence that inadequate intellectual property rights or weak enforcement of such rights are a barrier to technology transfer. A 2010 study by the World Bank examines precisely this issue in the context of renewable energy production.

"When enforcement of intellectual property rights (IPR) is perceived to be weak, foreign firms may not be willing to license their most sophisticated technologies, for fear that competitors will use it-which is the situation for wind equipment in China. Weak IPR enforcement also discourages foreign subsidiaries from increasing the scale of their R\&D activities and foreign venture capitalists from investing in promising domestic enterprises." (World Bank, 2010, p.309)

Consider Figure 2 below which maps the intellectual property rights performance of nations across the globe in the wind power industry. While Brazil, China ${ }^{4}$, India and Turkey have all received investments in local manufacturing and R\&D, very few patents are registered in these nations presumably due to their weak IPR regimes (World Bank, 2010). ${ }^{5}$ Alternatively, one could conclude that this is due to the lack of inventive capacity, necessary skills and knowledge within these nations.

\footnotetext{
4 Note that this reflects an overall increase in patenting in China (WIPO, 2013).

5 According to the World Bank (2010), the composition of the IPR performance measure is drawn from published patent data from U.S., Japanese, European, and international patent application databases, annual reports, and Web sites of Vestas, General Electric,Gamesa, Enercon, and Suzlon, as well as Dedigama 2009. They make a point of noting that a country's IPR score reflects its ranking according to an IPR index based on the strength of its intellectual property protection policies and their enforcement.
} 


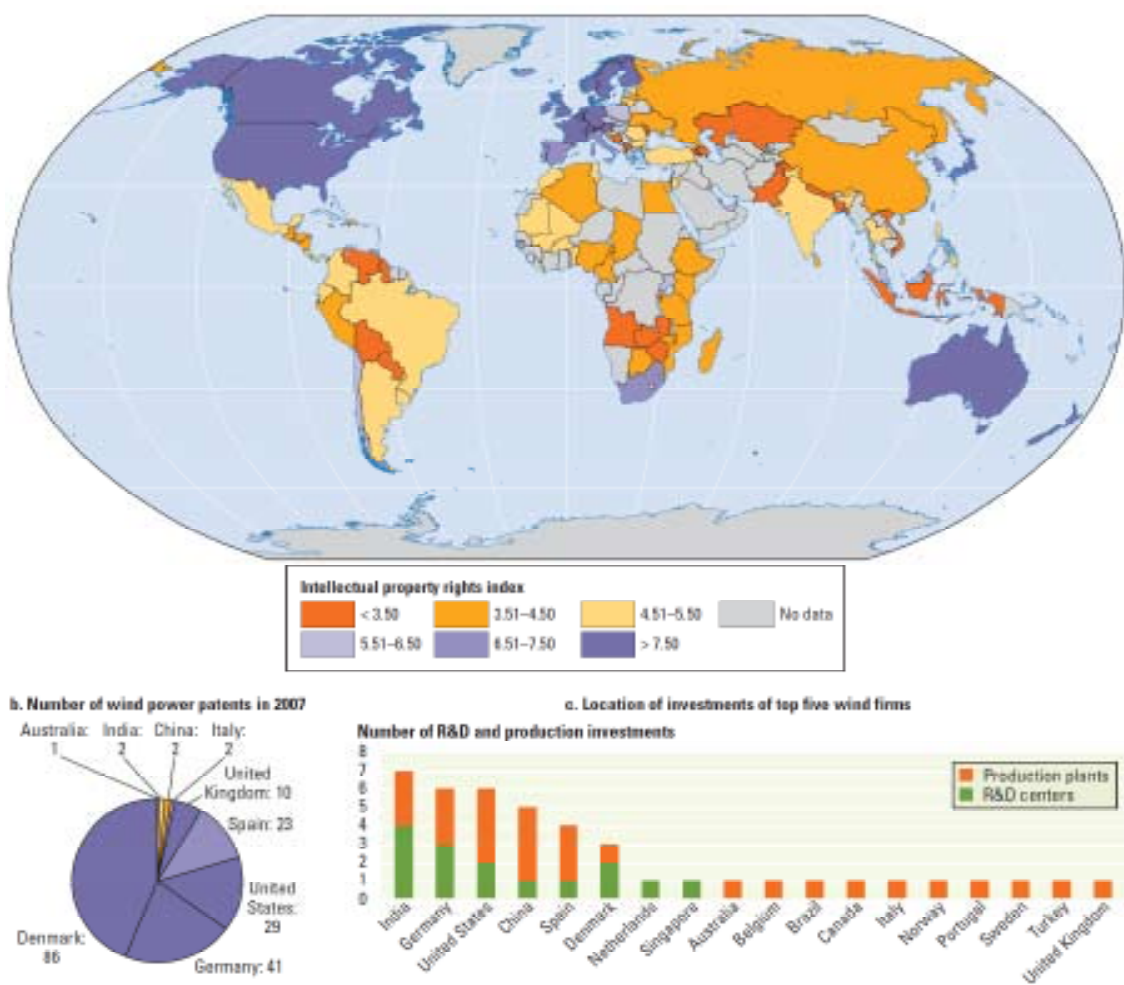

Figure 2. Middle-income countries are attracting investments from the top five wind equipment firms, but weak intellectual property rights constrain technology transfers and R\&D capacity

Source: World Bank (2010, p.309).

According to the World Bank study, in the context of low-income countries, weak IPRs do not appear to be a barrier to the transfer of sophisticated climate-smart technologies. Clear, predictable and well-enforced IP rights can facilitate technology transfers to these nations. While the World Bank's World Development Report emphasizes the importance of other forms of IP protection, strong trade secret protection is also critical. It has been shown, in particular, to be relevant to the growth of small businesses, which empirical studies have shown to play a substantial role in innovation (Lerner 1995; Lemley 2008). Given that trade secrets are significantly less expensive to obtain, maintain and enforce relative to patents, small businesses rely disproportionately on trade secrets to protect their innovations. Due to the risks of industrial espionage, this is particularly true of innovative small businesses in high technology sectors. In the words of Stanford Law School 
Professor Mark Lemley, "Trade secret law develops as a substitute for the physical and contractual restrictions those companies would otherwise impose in an effort to prevent a competitor from acquiring their information" (Lemley, 2008, p.335). Strong trade secret protection provides employers with a degree of freedom otherwise unavailable to them. That is, it allows firms to seek out and hire employees based on their skills rather than loyalty. Employees are assigned responsibilities where their talents are the most beneficial, instead of making those decisions based on the risks of compromising confidential information.

The security of trade secrets and the strength of trade secret protection will also influence a firm's investment decisions. The U.S. Chamber of Commerce study, cited above, notes that a lack of trade secret protection or ineffective enforcement of relevant laws may lead companies to "make excessive investments in ensuring physical protection for their secrets, rather than in innovation" (U.S. Chamber of Commerce, 2013, p.6). These findings are also evident in the empirical work of Png (2012), who analyzes the link between the historical evolution of trade secret protection in the United States and the corresponding levels of R\&D investment. Png finds that greater trade secret protection is correlated with greater R\&D investments in R\&D-intensive industries.

Finally, the work of Kanwar and Evenson (2009) examines the relationship between higher levels of IP protection and R\&D spending in a sample of 44 countries over the period 1981-2000. They fail to find a robust correlation between R\&D intensity (R\&D expenditure as a percentage of GDP) and IP strength. Hall and Helmers conclude that it is impossible to draw clear conclusions from the literature on the link between intellectual property rights and domestic development. "While there exists some coherent evidence pointing to the importance of IPRs for domestic innovation, especially in certain industries, there is also convincing (historical) evidence questioning the robustness of this relationship." (Hall and Helmers, 2010, p.17) By contrast, Park and Lippoldt (2008) do find a positive correlation between the strength of IPRs and the number of patent applications by developing countries in addition to R\&D expenditure as a share of GDP. They conclude that stronger IP rights are beneficial to domestic development of technology in developing nations and, as such, their findings appear to be more in line with the overwhelming direction of the economic literature on the topic.

An extensive review of the literature on patent protection is provided by Hall and Helmers (2010), in which they conclude that stronger intellectual property rights encourage innovation in general. Moreover, IP protection seems to facilitate technology transfer to middle-income countries with sufficient absorptive capacity. Within the clean technology sector, there is an 
extensive variety of different technologies available for emission reductions. In addition, a significant proportion of these innovations as well as the underlying technologies are in the public domain. It is expected that the majority of technological progress will come from incremental improvements of existing off-patent technologies, especially as technologies are adapted for local conditions. Although these incremental innovations may be patentable, there is plenty of room in the market scope for competing technologies and which limits the role specific patents may play for technological progress in this area (Hall and Helmers, 2010; Johnson and Lybecker, 2009a).

\section{The SPeCific Challenges Faced BY DEVELOPING COUNTRIES}

While there is a small literature focused on the link between intellectual property rights and the development and dissemination of environmental innovations, very few studies examine the experience of developing countries (Popp and Newell, 2009). However, this is a very important issue since there is so much debate over the role of intellectual property in facilitating or inhibiting the adoption of clean technologies in developing countries. A focus on developing countries is critical because as described by Popp (2012), in $2010,75 \%$ of the growth in $\mathrm{CO}_{2}$ emissions came from non-OECD countries, and the emissions from these nations are projected to be double those of OECD nations by 2035. Given this, the design of policies that facilitate the transfer of clean technologies to developing nations has been a clear focus in climate negotiations.

Environmental innovation continues to be concentrated in developed nations. Accordingly, the lion's share of patents for these technologies is issued by the patent offices of industrialized economies. Table 2 below shows the share of climate patented inventions by country, for the period 2007 through 2009. ${ }^{6}$ The United States, Germany and Japan clearly dominate this sector, though China does make the top ten list.

6 These calculations are based on PATSTAT data. The authors note that international patents refer to claimed priorities invented in the country as a share of world claimed priorities. Mean of 25 climate technology shares. 
Table 2. Top ten inventor countries in climate innovation and selected emerging economies

\begin{tabular}{llc}
\hline Rank & Country & Share of world climate patented inventions (2007-2009) \\
\hline 1 & USA & $19.0 \%$ \\
2 & Germany & $18.7 \%$ \\
3 & Japan & $17.5 \%$ \\
4 & South Korea & $5.6 \%$ \\
5 & France & $4.8 \%$ \\
6 & UK & $3.6 \%$ \\
7 & Italy & $3.4 \%$ \\
8 & Canada & $2.7 \%$ \\
9 & China & $1.7 \%$ \\
10 & The Netherlands & $1.6 \%$ \\
Total Top 10 & & $78.6 \%$ \\
18 & Taiwan, China & $0.9 \%$ \\
21 & India & $0.7 \%$ \\
22 & Russia & $0.5 \%$ \\
25 & Brazil & $0.4 \%$ \\
31 & South Africa & $0.2 \%$ \\
\hline
\end{tabular}

Source: Glachant, Dussaux, Ménière, and Dechezleprêtre (2013, p.5).

Figure 3 below takes a closer look at environmental innovation, by specific technology. ${ }^{7}$ Again, the most innovative nations listed above are among the most active in each of the technologies identified in figure. Figure 3 identifies the share of patent applications in energy-related technologies between 2006 and 2010. The graphs display data for solar energy, fuel cell technology, wind energy, and geothermal energy.

7 According to de Plooy (2013), the data is taken from the World Intellectual Property Organization (WIPO), specifically 'World intellectual property indicators - Tables and figures'. http://www.wipo.int/ipstats/en/wipi/figures. html\#overview. 

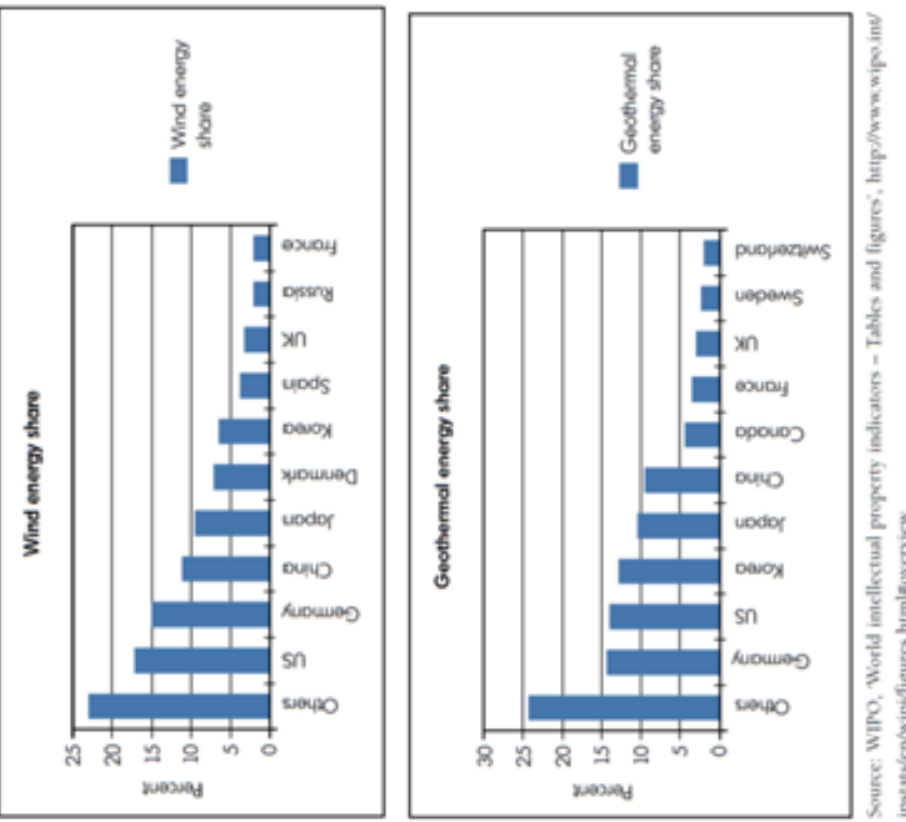

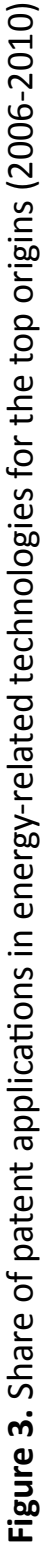
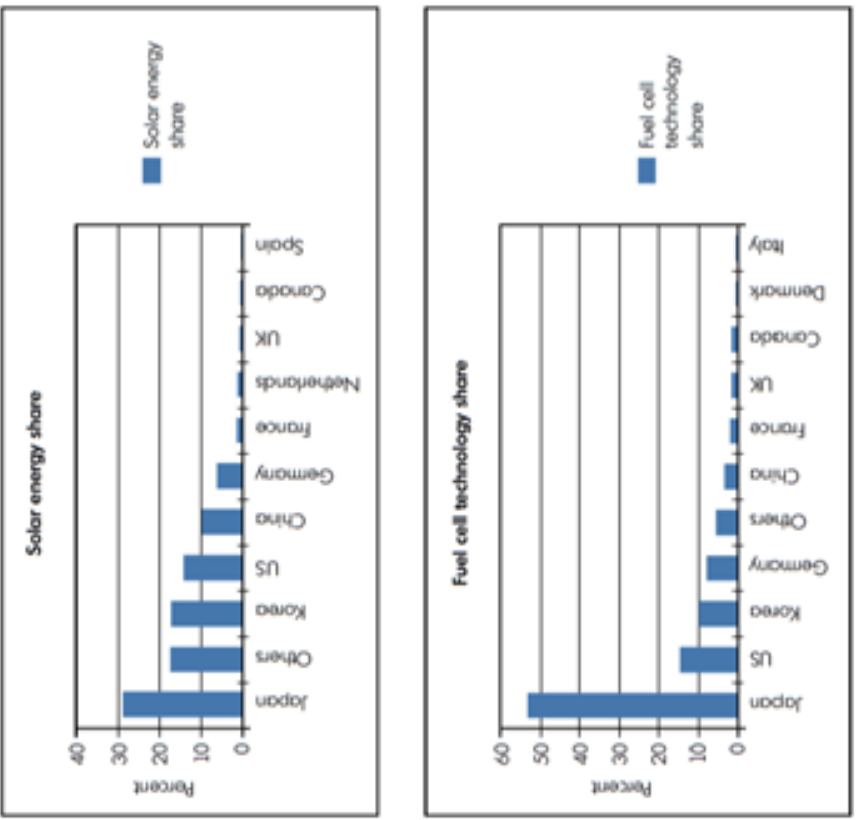
Recognizing that the majority of environmental innovation takes place in industrialized nations, it is valuable to examine what should be done to expand the rate of environmental research and development in all nations. In Table 3, the World Bank presents a summary of the key national policy priorities needed to facilitate environmental innovation, by national income level. These recommendations address a number of the challenges and problems surrounding environmental innovation: dual externalities, uncertainty, insufficient incentives, government regulation, and policy interventions (Groba and Breitschopf, 2013; Kalamova, Johnstone and Haščič, 2013; Popp, 2012; Popp, 2010, Hall and Helmers, 2010; Popp, Newell and Jaffe, 2009; Heal, 2009; Johnson and Lybecker, 2009a, 2009b, 2009c).

Table 3. Key national policy priorities for innovation in countries of different income levels

\begin{tabular}{ll}
\hline Countries & Main Policies \\
\hline \multirow{3}{*}{ Low-income } & $\begin{array}{l}\text { Invest in engineering, design, and management skills } \\
\text { Increase funding to research institutions for adaptation research, development, } \\
\text { demonstration, and diffusion } \\
\text { Increase links between academic and research institutions, the private sector, and } \\
\text { public planning agencies } \\
\text { Introduce subsidies for adopting adaptation technologies } \\
\text { Improve the business environment } \\
\text { Import outside knowledge and technology whenever possible }\end{array}$ \\
\hline & $\begin{array}{l}\text { Introduce climate- smart standards } \\
\text { Create incentives for imports of mitigation technologies and, in rapidly industrializing } \\
\text { countries, create long- term conditions for local production }\end{array}$ \\
Create incentives for climate- smart venture capital in rapidly industrializing countries \\
Middle-income & with a critical density of innovation n(such as China and India) \\
Improve the business environment \\
Strengthen the intellectual property rights regime \\
Facilitate climate- smart foreign direct investment \\
Increase links between academic and research institutions, the private sector, and \\
public planning agencies
\end{tabular}

Source: World Bank (2010, p.303). 
The 2010 World Development Report notes that stronger intellectual property rights should be a priority for all but the lowest-income nations. In addition, improvements in the business environment and greater funding for research institutions are widely recommended. Finally, innovation is universally enhanced by the removal of trade barriers in environmental technology sectors (World Bank, 2008a, 2008b; World Trade Organization, 2014). The World Trade Organization (WTO) describes this as a Win-Win-Win, pointing to the importance of trade negotiations in facilitating "the reduction or elimination of tariff and non-tariff barriers (NTBs). Domestic purchasers, including business and governments at all levels, will be able to acquire environmental technologies at lower costs. In addition, liberalizing trade in environmental goods will encourage the use of environmental technologies, which can in turn stimulate innovation and technology transfer." (World Trade Organization, 2014, p.1) The potential impact of removing trade barriers is striking. As estimated by the World Bank, "Eliminating tariff and nontariff barriers on clean energy technologies-such as cleaner coal, wind power, solar photovoltaics, and energy- efficient lighting-could increase their traded volume by 14 percent in the 18 developing countries that emit high levels of greenhouse gases." (World Bank, 2010, p.308) ${ }^{8}$

In an examination of six energy sectors (wind, solar, photovoltaic, concentrated solar power, biomass-to-electricity, cleaner coal, and carbon capture), a 2009 study by UK think tank Chatham House finds that most patenting activity is concentrated in large, developed economies. ${ }^{9}$ Of the six technology sectors considered, they found that for all but one of the top ten geographic locations of patent assignees or owners are OECD economies. The United States tops the list, followed by Japan, Germany, China, Korea,

8 The study lists these countries as: Argentina, Bangladesh, Brazil, Chile, China, Colombia, Arab republic of Egypt, India, Indonesia, Kazakhstan, Malaysia, Mexico, Nigeria, the Philippines, South Africa, Thailand, República Bolivariana de Venezuela, and Zambia.

9 It is important to note that the convention of utilizing patents as a measure of innovation is not without criticism. In a review of the value of patents as measures of innovation, Archibugi and Pianta (1996) describe both their advantages and disadvantages. Advantages: "They are a direct outcome of the inventive process, and more specifically of those inventions which are expected to have a commercial impact. They are a particularly appropriate indicator for capturing the proprietary and competitive dimension of technological change. Because obtaining patent protection is timeconsuming and costly, it is likely that applications are filed for those inventions which, on average, are expected to provide benefits that outweigh these costs. Patents are broken down by technical fields and thus provide information not only on the rate of inventive activity, but also on its direction. Patent statistics are available in large numbers and for a very long time series. Patents are public documents. All information, including patentees' names, is not covered by statistical confidentiality." Disadvantages: "Not all inventions are technically patentable. This is the case of software, which is generally legally protected by copyright. Not all inventions are patented. Firms sometimes protect their innovations with alternative methods, notably industrial secrecy. Firms have a different propensity to patent in their domestic market and in foreign countries, which largely depends on their expectations for exploiting their inventions commercially. In each national patent office, there are many more applications from domestic inventors than from foreigners. Although there are international patent agreements among most industrial countries, each national patent office has its own institutional characteristics, which affect the costs, length and effectiveness of the protection accorded. In turn, this affects the interest of inventors in applying for patent protection." (Archibugi and Pianta, 1996, pp.452-454) Notably, while it is a convenient way to measure innovation performance and technology trends, patent citation lags utilized to distinguish between incremental and radical innovations (quality) have historically been too short. 
and the UK (Lee, Lliev, and Preston, 2009). In line with the findings of Lanjouw and Mody (1996), Dechezleprêtre et al. (2011), and Popp (2012), the technologies of greatest use, measured by the percentage of patents that have corresponding applications in other countries, are almost exclusively from developed economies.

While the majority of environmental innovation emerges in developed countries, some developing countries are also making strides in this direction. The limited evidence that exists indicates that there is significant heterogeneity in innovative capacity across developing nations, and that countries fall into one of two groups (Hall and Helmers 2010). Emerging economies, primarily Brazil, China, India and Mexico, have begun to develop environmental technologies and gain a share in the global market for renewable energy technologies. In contrast, a larger group of less-developed countries have yet to make such progress. As in the case of the broader literature on technology development and dissemination, "the evidence on clean technologies suggests that a strengthening of IPRs for the group of emerging economies will most likely have a positive impact on the domestic development of technology and its transfer from developed economies. The available evidence does not allow drawing a similar conclusion in the case of less developed countries." (Hall and Helmers, 2010, p.29) While stronger patents and IP rights encourage technology transfer to developing nations, through imports, FDI and licensing, they appear to have a negligible effect on technology transfer to the lowest income nations.

For many developing nations, foreign direct investment (FDI) is a principal channel of technology transfer. Hall and Helmers evaluate the existing literature on the correlation between intellectual property rights enforcement and foreign direct investment (FDI). They write, "Considering the extensive evidence on FDI serving as a channel for technology transfer, this implies a positive relation between IPR enforcement and technology transfer through the channel of FDI. However, the literature also points to other important factors in attracting FDI, such as country risk and the availability of low-cost highly-skilled labor" (Hall and Helmers, 2010, p.499). In another study, Park and Lippoldt (2008) examine the relationship between the strength of intellectual property rights protection and technology transfer as proxied by inward FDI stocks and imports of goods and services. They analyze a sample of 120 countries over the 1990-2005 period and find that strong IP rights induce foreigners to transfer new technologies. The authors also find a positive correlation between the strength of IPRs and the number of patent applications by developing countries in addition to R\&D expenditure as a share of GDP. They conclude that stronger IP rights are beneficial to domestic development of technology in developing nations. 
Beyond FDI as a channel for technology transfer, several private initiatives are also in place that facilitate the transfer of environmental innovations. The Eco-Patent Commons were established in 2008 by IBM, Nokia, Sony and Pitney Bowes, coordinated by the World Business Council for Sustainable Development (WBCSD), and have since been joined by Bosch, DuPont, Xerox, Ricoh, Taisei, Dow Chemical, Fuji-Xerox, Hewlett Packard and Hitachi. Under this initiative firms "pledge" patents to the commons which are then available to third parties without charge, though the patent rights remain with the innovative firm. According to the Eco-Patent Commons website, the commons were "founded on the commitment that anyone who wants to bring environmental benefits to market can use these patents to protect the environment and enable collaboration between businesses that foster innovations. The objectives of the Eco-Patent Commons are: To provide an avenue by which innovations and solutions may be easily shared to accelerate and facilitate implementation to protect the environment and perhaps lead to further innovation; To promote and encourage cooperation and collaboration between businesses that pledge patents and potential users to foster further joint innovations and the advancement and development of solutions that benefit the environment." (World Business Council) Since the launch in January 2008, more than 100 patents have been pledged by thirteen companies.

Clearly exposure to new technologies is not sufficient for diffusion of the innovation. In order to bridge the gap between exposure and adoption an economy must possess an appropriate level of absorptive capacity (Png, 2012; Dechezleprêtre, Glachant, Haščič, Johnstone, and Ménière, 2011; World Bank, 2008a, among others). Figure 4 below describes the process, as depicted by the World Bank (2008a). This study creates an index of absorptive capacity, drawing on data on education, governance and macroeconomic stability. "Absorptive capacity depends on the overall macroeconomic and governance environment, which influences the willingness of entrepreneurs to take risks on new and new-to-the-market technologies; and the level of basic technological literacy and advanced skills in the population, which determines a country's capacity to undertake the research necessary to understand, implement, and adapt them." (World Bank, 2008a, p.25) Beyond these elements, the study notes that access to financing is also a key component to the absorption of new technologies. 


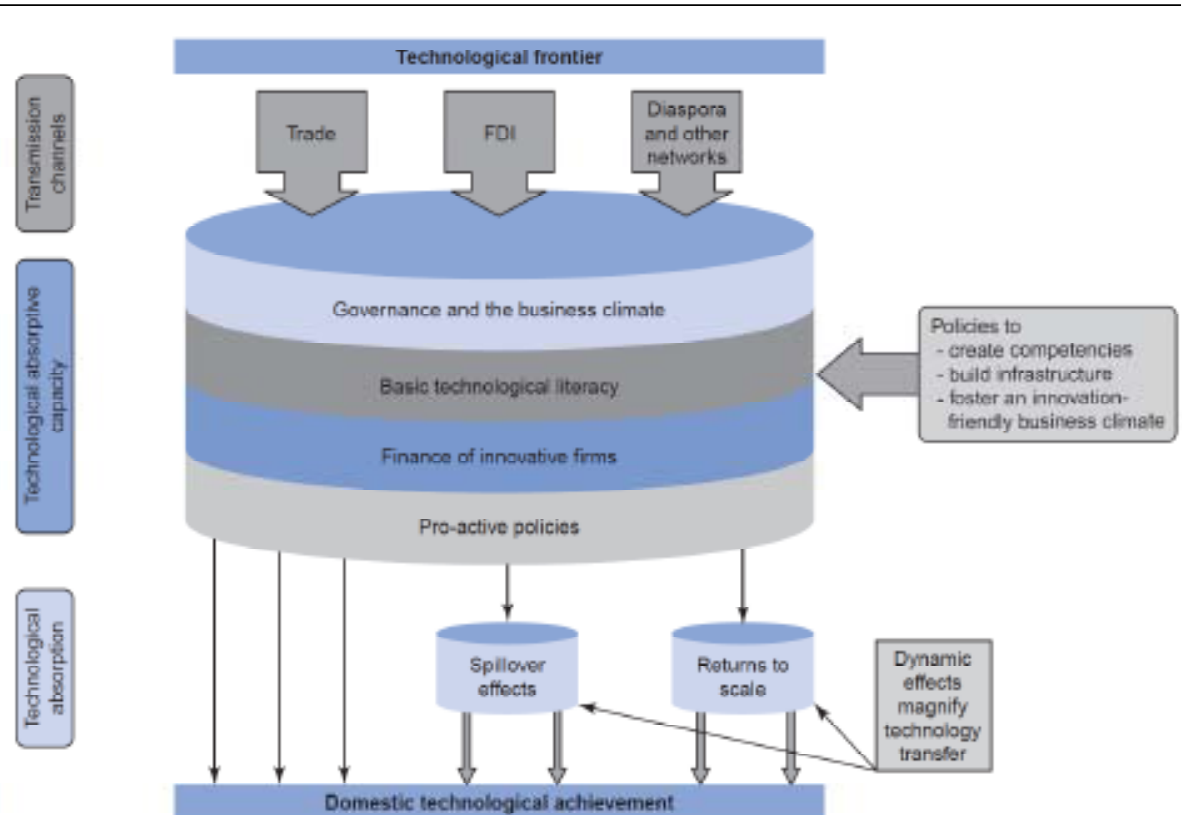

Figure 4. Domestic absorptive capacity both conditions and attracts external flows

Source: World Bank (2008a, p.25).

While absorptive capacity is a necessary condition, it must be complemented by effective IP protection. In a review of the empirical evidence on intellectual property protection and technology transfer, Hall and Helmers examine the importance of both of these elements.

"[Absorptive capacity] facilitates technology transfer through licensing, which is the channel involving the most disembodied technology transfer external to the multinational company ... absorptive capacity is necessary to make use of and learn from imported technology, but [the country is] more likely to receive the technology if the foreign firm from which it comes feels that its ownership rights will be protected. If the absorptive capacity is present but IP protection is weak foreign firms will tend to establish distribution rather than manufacturing subsidiaries" (Hall and Helmers, 2010, p.12).

In addition, technology transfer is enhanced by openness to trade. Dechezleprêtre, Glachant, Haščič, Johnstone and Ménière (2011) demonstrate that the dissemination of information is more likely if a nation is more engaged in international trade. However, they also show that technology 
transfer is less likely to occur if the nation is already pursuing similar projects domestically.

While the majority of evidence on absorptive capacity focuses on the role it plays in facilitating technology transfer, there is limited evidence that greater absorptive capacity also enhances innovation. Admittedly, for most developing nations the focus is on attracting technology transfer or facilitating adaptive R\&D rather than innovation. As noted by Popp (2012) and others, the knowledge spillovers generated by technology transfers are very important. "For technology transfer, policy must manage a careful balancing act, so as to promote knowledge spillovers from technology transfer to the extent possible without discouraging investors from coming into the country at all." (Popp, 2012, p.34) Dechezleprêtre, Glachant, Haščič, Johnstone and Ménière (2011) find that countries with greater technological capacity are more equipped to develop their own innovations. This is particularly true in developing nations which also benefit from the reduced need for technology transfer from abroad (Popp, 2012). In a study of technology transfer to developing nations, Haščič and Johnstone use data from patent applications and find that increases in absorptive capacity increase wind energy patent applications filed in developing nations by developed country innovators (Haščič and Johnstone 2011). They go on to demonstrate that absorptive capacity is more important than traditional technology transfer policies, as well as the Clean Development Mechanism (CDM), a finding that has been shown in numerous other studies (World Bank, 2008a; Png, 2012; Dechezleprêtre, Glachant, Haščič, Johnstone, and Ménière, 2011, among others).

In their current form, the legal obligations of technology transfer (from developed to developing nations) under the UNFCCC/Kyoto framework are both vague and non-binding. Van Hoorebeek and Onzivu (2010) describe the Clean Development Mechanism (CDM) of the Kyoto Protocol not as a mechanism for technology transfer, but rather as a mechanism to facilitate investing in sustainable development projects for Certified Emission Reduction Credits (CER) in developing countries. While firms have an incentive to engage in the CDM since it is frequently less costly to achieve required emission reductions in developing countries, the benefits are more far-reaching. Costa, Doranova and Eenhoorn (2008) present case study evidence from Dutch waste management firms which shows that even firms exempt from emission limits pursue CDM projects.

In a deeper exploration of the benefits of the CDM, Dechezleprêtre, Glachant, and Ménière (2008) consider whether projects transfer 'hardware' (equipment and machinery) or 'software' (knowledge, skills and know-how). The study includes 644 CDM projects registered with the Executive Board of the UNFCCC, with 279 projects (43\%) involving technology transfer. Most 
of the projects transfer knowledge (101) or knowledge and equipment (121), as opposed to just equipment (57). Larger projects and those involving a subsidiary of a developed country company are more likely to involve technology transfers. While the great majority of projects (73\%) are concentrated in four countries, Brazil, China, India and Mexico, there is significant variety in the types of projects across countries. Notably $59 \%$ of projects in China involve the transfer of technology, while a mere $12 \%$ of Indian projects do. In a more recent study, Seres, Haites and Murphy (2009) consider 3296 registered and proposed CDM projects. While they find that fewer projects (36\%) involve some technology transfer, their results do confirm that technology transfer is more common for larger projects. It is encouraging that this is a marked increase from earlier studies that found approximately one third of projects transferred technology (de Coninck, Haake and van der Linden, 2007). Although Seres et al. also confirm that the rate of technology transfer has always been significantly lower in India; their findings indicate that the rate of technology transfer has decreased appreciably for Brazil and India. To account for this they note that "more projects of a given type in a host country tend to lower the rate of technology transfer for future projects, indicating the development of a broader technological capacity in the country." (Seres et al., 2009, p.4926) Again this result provides an encouraging contrast to an earlier study that found that less than $1 \%$ of CDM projects were likely to contribute significantly to sustainable development in the host country (Sutter and Parreno, 2007). Clearly there are marked differences in the technology that is transferred and the opportunities for developing nations to utilize the knowledge and skills to make additional improvements and further lower their emission levels.

While adaptive research and development (R\&D) is an essential component of environmental innovation by developing nations, they have not yet made adequate progress in this area. Adaptive innovation is essential to finding appropriate technologies for local conditions. Consider the following examples, highlighted in Popp (2012). Wang (2010) recounts the Chinese policy of evaluating potential CDM projects with an eye on local conditions. The government does not embrace technologies that are new to Chinese conditions since the risk of poor adaptation to local conditions would increase the risk to the CDM credits, lowering their value. In a similar vein, given slower prevailing wind speeds in India relative to Europe, wind turbines must be adapted to generate electricity (Kristinsson and Rao, 2007). Finally, de la Tour, Glachant and Ménière (2011) find that photovoltaic manufacturers in China adapt production processes, replacing costly capital with less expensive labor. 
The World Bank 2010 World Development Report notes that while it is more cost-effective to adopt technologies from abroad rather than to reinvent them, there are some circumstances in which no international technological solution exists for a local problem. As an example, the report cites crops and growing methods that may need to be adapted to local climate, drought, soil and technological conditions. Popp (2012) describes the importance of adaptive innovation, in the context of both local and global benefits as well as immediate and eventual challenges.

Luo, Lovely and Popp (2013) study the patenting history of 806 Chinese solar photovoltaic firms between 1998 and 2008, finding that firms whose leaders have international experience are more likely to patent. In addition, patenting activity also increases for neighboring firms who reap spillover benefits from the intellectual returnees. Given this success, it is not surprising that recruiting high-skill returnees is a strategic imperative for China, emphasized in three national middle- and long-term plans. The authors note that China's policies now not only provide incentives for the return of émigrés, but also include imperatives for overseas experiences in some sectors. While recruiting intellectual returnees has brought clear benefits to China, the authors recommend caution. They describe the potential for trade conflicts as emerging economies enter high-tech sectors previously dominated by developed nations. In addition, a "final caution relates to the fine line between technology transfer and intellectual property espionage ... as more scientists return home with human capital acquired in technologically advanced economies, challenges grow for resolution of intellectual property conflicts within a weal global IP protection architecture." (Luo, Lovely and Popp, 2013, pp.27-28)

These findings are echoed in numerous other studies. The 2010 World Bank World Development report states, there "is no evidence that overly restrictive IPRs have been a big barrier to transferring renewable energy production capacity to middle-income countries ... . In low-income countries, weak IPRs do not appear to be a barrier to deploying sophisticated climate-smart technologies." (World Bank, 2008a, p.310) Barpujari and Nanda analyze the IPR regimes of five Asian nations at differing stages of economic development: China, India, Indonesia, Malaysia and Thailand. Following an assessment of the IPR environment in each nation, based on TRIPS-compatibility, enforcement and TRIPS-Plus provisions, the authors find that "the contention that weak IPRs in developing countries constitute the biggest barrier to technology transfer seems to be untenable." (Barpujari and Nanda, 2012, p.23) They do, however, acknowledge that developing nations need to make additional progress in enforcement and building administrative 
capabilities, though this is dependent upon securing the necessary financial and human resources.

Extending these conclusions, a recent study by the UK think tank Chatham House suggests that weak intellectual property rights are a barrier to technological diffusion. They conclude that intellectual property protection is a factor in the speed of diffusion. Specifically, many innovators are established industrial giants, and their perception of the strength of intellectual property protection in developing countries determines the speed of dissemination to the extent that it can be expected that weak intellectual property protection would slow the rate of technology transfer to some developing countries. The study notes that this is dependent on the willingness of such firms "to license for production or sale [and therefore] may depend on their confidence that they can do so without losing control." (Lee, Lliev and Preston, 2009, p.21) Perez Pagatch (2011) notes that this is confirmed by leading firms, which "cite weak intellectual property protection in host countries among the reasons for withholding their latest technologies from certain markets." (Perez Pagatch, 2011, p.9) Further confirmation comes from Awokuse and Yin (2010) who study the relationship between imports and IPR protection in China, utilizing panel data for 1991-2004. They find that China's imports increase with stronger patent protection and that this effect is most dominant for hightech industries.

Taking the longer view, it is critical to assist developing nations in building their own productive and technological capacity in the environmental goods sector. Jha (2009) discusses the importance of access to finance, venture capital and supportive policies by the government such as renewable energy regulations, feed-in tariffs and concessionary loans. Each of these is essential for market creation in renewable energy within developing nations. Although a number of industrialized nations, as well as China and South Korea, provide financial support through green fiscal stimulus packages, smaller developing countries may not have access to such resources. As described by Sugathan, these circumstances strengthen "the case for bilateral and multilateral support for these developing countries, including as part of a package within the UNFCCC. The World Bank report calls for smarter trade as an adjunct to freer trade, and proposes bundling trade liberalization with a package of technical and financial assistance." (Sugathan, 2009, p.7)

In stark contrast to the policies that incentivize and encourage innovation, the presence of tariffs and nontariff barriers greatly inhibits the development, adoption and use of environmental technology. In a study of 18 developing countries that emit high levels of greenhouse gases, the World Bank (2010) concludes that the elimination of tariff and nontariff barriers on clean technologies (they specify: cleaner coal, wind power, solar photovolta- 
ics, and energy-efficient lighting) could increase their traded volume by $14 \%$. The authors argue that trade barriers on imports raises domestic prices, making energy efficient technologies less competitive and cost-ineffective. Consider the following examples: In Egypt, tariffs on photovoltaic panels average $32 \%$, which is ten times the tariff they are subject to in high-income OECD member countries. In Nigeria, photovoltaic panels face tariffs of $20 \%$ and nontariff barriers of $70 \%$. Due to tariffs on biofuels in Brazil and subsidies to biofuel producers by OECD countries, investments are not being made in biofuels in Brazil, the world's most efficient and least-cost ethanol producer. Brazilian ethanol production grew a modest $6 \%$ between 2004 and 2005. By comparison, the United States and Germany increased production by 20 and $60 \%$ respectively, protecting their producers with tariffs of $25 \%$ in the U.S. and more than $50 \%$ in the E.U. Relying on market forces and removing the tariffs, nontariff barriers and subsidies should reallocate production to the most efficient biofuel producers, allowing for increases in production and more competitive pricing ${ }^{10}$.

\section{CONCLUSIONS}

It is important to be aware of the lessons learned about innovation and the development and dissemination of technologies: innovation responds quickly to incentives; innovation in a given field experiences diminishing returns over time; the social returns to environmental research are high while the private returns may not be; and the type of policy used affects the nature, adoption and dissemination of innovations. For its part, technology development, diffusion and dissemination are best encouraged with market forces and incentives. However, in the case of environmental technologies, the presence of dual externalities inhibits the innovative process. Without effective public policy markets alone are not likely to provide sufficient incentives for the development of environmental innovations. Innovative industries would benefit from greater predictability in each of these areas. As described in the earlier studies, "in this context it is essential for policymakers to find a balance: encouraging competition while guaranteeing a large market for minimum economic scale, reducing uncertainty about future resource prices while keeping alternatives open, offering rights of exclusion to intellectual property holders while not curtailing the ability of sequential innovators to build upon past successes, promoting social goals while respecting market pressures." (Johnson and Lybecker, 2009a, p.5) This continues to be true,

10 For additional information on the data utilized in these studies, please see the World Bank (2010) study, or the following references. Tsebelis (2002), Dolsak (2001), Vogel (2005), Bernauer and Caduff (2004), and Bernauer (2003). 
and even more so in developing nations seeking to develop and adopt clean technologies.

Key findings from this review of recent literature on environmental innovation:

- Environmental innovation is characterized by dual externalities and private underinvestment in research and development (R\&D) due to knowledge spillovers and environmental externalities.

- In both the development and the diffusion of clean technology, the challenges surrounding uncertainty loom large. From beginning to end clean technology innovation is characterized by uncertainty: uncertainty about actual costs, uncertainty about the end-product of a research process, uncertainty about the reception by the market, uncertainty about the ability to appropriate the returns to research while competitors try to produce similar results, uncertainty about current and future policy platforms, uncertainty surrounding the pricing of competing as well as complementary goods, and uncertainty about regulatory impacts on the research process and end-result. This is exacerbated by the uncertainty surrounding the rate of innovation itself which complicates any estimate of global climate change, making it difficult to substantiate the reasons for further research funding.

- While diffusion and adoption are paramount to the ultimate usefulness of a new technology, little scholarship has focused specifically on the international transfer of environmental innovations. Moreover, even within the work on international technology transfer, the majority of work has been done on highly developed economies.

- In this sector, developing nations fall into two groups: emerging economies, primarily Brazil, China, India and Mexico, are developing environmental technologies while a large group of less-developed countries are not.

- In the case of developing nations in general, studies find a positive correlation between the strength of intellectual property rights (IPRs) and the domestic development of environmental innovations. Domestic development increases the likelihood that environmental innovations are appropriate for local conditions and that existing technologies can be successfully adapted to suit local environmental challenges. To ensure such technologies evolve, domestic innovation should be supported by strong IPRs.

- Although the value of patents, and other forms of protection, varies across countries, across industries and across innovations, numerous studies have documented the reasons to encourage strong patent law. A majority of economists agree that strong intellectual property rights are an essential prerequisite to the development of environmental technologies. Effective IPR protection also appears to play a role in 
enabling foreign direct investment (FDI) and makes a country a more attractive destination for such FDI or various types of commercial partnerships and cooperation.

- Other factors are highly determinative as well. This includes the presence of tariffs and non-tariff barriers, which greatly inhibit the development, adoption and use of clean technology; the presence of qualified individuals, including management with industrialized country training and educational backgrounds; environmental regulations and other regulatory measures; and the size of the (local or regional) market.

The market for environmental technologies, as described above, is characterized by significant uncertainties and risks. These factors complicate the transfer of technologies, particularly to developing nations. Moreover, in the face of dual externalities, this presents distinct challenges for their adoption of clean technology innovation. While market forces and market failures shape the environmental technology sector, political and cultural forces further complicate every aspect.

As scholars continue to analyze when, where, why and how clean technology innovations are developed and adopted, it is essential that government policymakers aim to reduce uncertainty in the market. This continues to be a field of increasing future importance, and a rich area for continued academic study and analysis. Consumers, government policymakers and innovators would all benefit from a greater understanding of the process of technological change in the development, diffusion and financing of clean technologies.

\section{References}

Allan, C., Jaffe, A.B. \& Sin, I. (2014). Diffusion of Green Technology: A Survey. Motu Working Paper No. 14-04. Retrieved from: http://ssrn.com/ abstract $=2422682$.

Anderson, S.T. \& Newell, R.G. (2004). Information programs for technology adoption: the case of energy-efficiency audits. Resource and Energy Economics, 26(1), 27-50.

Archibugi, D. \& Pianta, M. (1996). Measuring technological change through patents and innovation surveys. Technovation, 16(9), 451-468.

Awokuse, T. O. \& Yin, H. (2010). Does Stronger Intellectual Property Rights Protection Induce More Bilateral Trade? Evidence from China's Imports. World Development, 38, 1094-1104.

Barpujari, I. \& Nanda, N. (2012). Are Weak IPRs Acting as Barriers to Transfer of Climate Friendly Technologies: Assessing IPR Regimes in Five Asian Countries. The Energy and Resources Institute, TERI-NFA Working Paper No.2. 
Bernauer, T. (2003). Genes, Trade, and Regulation: The Seeds of Conflict in Food Biotechnology. Princeton, NJ: Princeton University Press.

Bernauer, T., \& Caduff, L. (2004). In Whose Interest? Pressure Group Politics, Economic Competition and Environmental Regulation. Journal of Public Policy, 24(1), 99-126.

Copenhagen Economics (2010) Innovation of Energy Technologies: the Role of Taxes, Informed Decisions, Copenhagen Economics, November 2010.

Costa, I., Doranova, A. \& Eenhoorn, G.-J. (2008). Beyond the emission market: Kyoto and the international expansion of waste management firms. UNU-Merit Working Paper Series 2008-020.

De Coninck, H.C., Haake, F. \& van der Linden, N.H. (2007). Technology transfer in the Clean Development Mechanism. ECN Energy Research Centre of the Netherlands, Paper ECN-E-07-009.

De la Tour, A., Glachant, M. \& Ménière, Y. (2011). Innovation and international technology transfer: The case of the Chinese photovoltaic industry. Energy Policy, 39, 761-770.

De Plooy, P. (2013). Technology Diffusion Through Intellectual Property Rights: Innovating to Combat Climate Change, South African Institute of International Affairs (SAlIA), Occasional Paper No. 144.

Dechezleprêtre, A., Glachant, M., Haščič, I., Johnstone, N. \& Ménière, Y. (2011). Invention and transfer of climate change mitigation technologies on a global scale: A study drawing on patent data. Review of Environmental Economics and Policy, 5(1), 109-130.

Dedigama, A.C. (2009). International Property Rights Index (IPRI): 2009 Report. Washington, DC: Property Rights Alliance.

Dolsak, N. (2001). Mitigating Global Climate Change: Why Are Some Countries More Committed than Others? Policy Studies Journal, 29(3), 414-36.

Freeman, R. \& van Reenen, J. (2009). What if Congress Doubled R\&D Spending on the Physical Sciences? Center for Economic Performance, London, England, Center for Economic Performance Discussion Paper No.931.

Glachant, M., Dussaux, D. Ménière, Y., \& Dechezleprêtre, A. (2013). Greening Global Value Chains: Innovation and the International Diffusion of Technologies and knowledge. World Bank, Washington, DC.

Groba, F., \& Breitschopf, B. (2013). Impact of Renewable Energy Policy and Use on Innovation: A Literature Review. Deutsches Institut fur Wirtschaftsforschung (DIW Berlin), Berlin, Discussion Paper 1318.

Hall, B.H. (2014). Does patent protection help or hinder technology transfer, In: S. Ahn, B.H. Hall, K. Lee (Eds.), Intellectual Property for Economic Development: Issues and Policy Implications. Cheltenham, UK Northampton, MA, Edward Elgar.

Hall, B.H. \& Helmers, C. (2010). The Role of Patent Protection in (Clean) Technology Transfer. Santa Clara High Technology Law Journal, 26(4), 487-532. 
Hall, B.H. \& Helmers, C. (2013). Innovation and diffusion of clean/green technology: Can patent commons help? Journal of Environmental Economics and Management, 66(1), 33-51.

Halme, M. \& Korpela, M. (2013). Responsible Innovation Toward Sustainable Development in Small and Medium-Sized Enterprises: a Resource Perspective. Business Strategy and the Environment, paper accepted for publication. Retrieved from: http://onlinelibrary.wiley.com/doi/10.1002/ bse.1801/abstract

Haščič, I. \& Johnstone, N. (2011). CDM and International Technology Transfer: Empirical Evidence on Wind Power. Climate Policy, 11(6), 1303-1314.

Hassett, K.A. \& Metcalf, G.E. (1995). Energy tax credits and residential conservation investment: Evidence form panel data. Journal of Public Economics, 57, 201-217.

Heal, G. (2009). The Economics of Renewable Energy. NBER Working Paper No. 15081.

Henderson, R. \& Newell, R.G. (2010). Accelerating Energy Innovation: Insights from Multiple Sectors, NBER Working Paper No. 16529.

Howarth, R.B., Haddad, B.M. \& Paton, B. (2000). The economics of energy efficiency: Insights from voluntary participation programs. Energy Policy, 28, 477-486.

Jaffe, A.B \& Stavins, R.N. (1995). Dynamic incentives of environmental regulations: The effects of alternative policy instruments on technology diffusion. Journal of Environmental Economics \& Management, 29, 4363.

Jha, V. (2009). Trade Flows, Barriers and Market Drivers, in Renewable Energy Supply Goods, International Center for Trade and Sustainable Development, ICTSD Issue Paper No.10.

Johnson, D.K.N. \& Lybecker, K.M. (2009a). Innovating for an uncertain market: A literature review of the constraints on environmental innovation. Colorado College Working Paper 2009-06.

Johnson, D.K.N. \& Lybecker, K.M. (2009b). Challenges to technology transfer: A literature review of the constraints on environmental technology dissemination. Colorado College Working Paper 2009-07.

Johnson, D.K.N. \& Lybecker, K.M. (2009c). Financing environmental improvements: A literature review of the constraints on financing environmental innovation. Colorado College Working Paper 2009-08.

Kalamova, M., Johnstone, N. \& Haščič, I. (2013). Implications of Policy Uncertainty for Innovation in Environmental Technologies: The Case of Public R\&D Budgets. In: V. Constantini, M. Mazzanti (Eds.), The Dynamics of Environmental and Economic Systems (pp. 99-116). Berlin-Heidelberg: Springer.

Kanwar, S. \& Evenson, R. (2009). On the Strength of Intellectual Property Protection that Nations Provide. Journal of Development Economics, 90, 50-56. 
Keller, W. (2004). International technology diffusion, Journal of Economic Literature, 42, 752-782.

Kemp, R. (1997). Environmental Policy and Technical Change. Cheltenham, UK - Northampton, MA: Edward Elgar.

Kristinsson, K. \& Rao, R. (2007). Learning to Grow: A Comparative Analysis of the Wind Energy Sector in Denmark and India. Danish Research Unit for Industrial Dynamics, DRUID Working Paper 07-18.

Lanjouw, J.O. \& Mody, A. (1996). Innovation and the international diffusion of environmentally responsive technology. Research Policy, 25(4), 549571.

Lee, B., Lliev, L. \& Preston, F. (2009). Who Owns Our Low Carbon Future? London: Chatham House.

Lemley, M. (2008). Surprising Virtues of Treating Trade Secrets as IP Rights. Stanford Law Review, 61(2), 311.

Lerner, J. (1995). The Importance of Trade Secrecy: Evidence from Civil Litigation. Harvard Business School Working Paper No. 95-043. Retrieved from: http://ssrn.com/abstract $=6089$

Luo, S., Lovely, M.E. \& Popp, D. (2013). Intellectual Returnees as Drivers of Indigenous Innovation: Evidence from the Chinese Photovoltaic Industry. NBER Working Paper No. 19518.

Mansfield, E. (1986). Patents and Innovation: An Empirical Study. Management Science, 32(2), 173-181.

Metcalf, G.E. \& Hassett, K.A. (1999). Measuring the energy savings from home improvement investments: Evidence from monthly billing data. The Review of Economics and Statistics, 81, 516-528.

Moser, P. (2005), How Do Patent Laws Influence Innovation? Evidence from Nineteenth-Century World's Fairs. American Economic Review, 95(4), 1214-1236.

Mulder, P., de Groot, H.L.F. \& Hofkes, M.W. (2003). Explaining slow diffusion of energy-saving technologies; a vintage model with returns to diversity and learning-by-using. Resource and Energy Economics, 25(1), 105-126.

Nijkamp, P., Rodenburg, C.A. \& Verhoef, E.T. (2001). The adoption and diffusion of environmentally friendly technologies among firms. International Journal of Environmental Technology and Management, 1(1-2), 87-103.

Park, W.G. \& Lippoldt, D.C. (2008). Technology Transfer and the Economic Implications of the Strengthening of Intellectual Property Rights in Developing Countries. OECD Trade Policy Working Papers No. 62.

Perez Pugatch, M. (2011). Intellectual Property and the Transfer of Environmentally Sound Technologies. Global Challenges Report, Geneva: WIPO.

Plumer, B. (2013). Four charts that show the U.S. spends too little on energy research. The Washington Post, 9 April 2013. Retrieved from: http:// www.washingtonpost.com/blogs/wonkblog/wp/2013/04/09/threecharts-that-show-the-u-s-spends-too-little-on-energy-research/. 
Png, I.P.L. (2012). Law and Innovation: Evidence from State Trade Secrets Laws. Retrieved from: http://ssrn.com/abstract=1755284.

Popp, D. \& Newell, R.G. (2009). Where Does Energy R\&D Come From? Examining Crowding Out from Environmentally-Friendly R\&D. NBER Working Paper No. 15423.

Popp, D., Newell, R.G. \& Jaffe, A. (2010). Energy, the Environment, and Technological Change. In: B.H. Hall, N. Rosenberg. (Eds.), Handbook of the Economics of Innovation (pp. 873-972). Amsterdam: Elsevier-North Holland.

Popp, D. (2004). ENTICE: Endogenous technological change in the DICE model of global warming. Journal of Environmental Economics and Management, 48, 742-68.

Popp, D. (2010). Innovation and Climate Policy. NBER Working Paper No. 15673.

Popp, D. (2012). The Role of Technological Change in Green Growth. NBER Working Paper No. 18506.

Reppelin-Hill, V. (1999). Trade and environment: An empirical analysis of the technology effect in the steel industry. Journal of Environmental Economics and Management, 38, 283-301.

Seres, S., Haites, E. \& Murphy, K. (2009). Analysis of Technology Transfer in CDM projects: An Update. Energy Policy, 37(11), 4919-4926.

Stewart, R.B., Kingsbury, B. \& Rudyk, B. (2009). Climate Finance: Regulatory and Funding Strategies for Climate Change and Global Development. New York: New York University Press.

Sugathan, M. (2009). Liberalization of Climate-friendly Environmental Goods: Issues for Small Developing Countries. International Centre for Trade and Sustainable Development, ICTSD Information Note No. 14.

Sutter, C. \& Parreno, J.C. (2006). Does the current Clean Development Mechanism (CDM) deliver its sustainable development claim? An analysis of officially registered CDM projects. Climate Change, 84, 75-90.

Tsebelis, G. (2002). Veto Players: How Political Institutions Work. Princeton, NJ: Princeton University Press.

U.S. Chamber of Commerce (2013). The Case for Enhanced Protection of Trade Secrets in the Trans-Pacific Partnership Agreement. Washington, D.C.: U.S. Chamber of Commerce.

Van Hoorebeek, M. \& Onzivu, W. (2010). The Eco-patent Commons and Environmental Technology Transfer: Implications for Efforts to Tackle Climate Change. Carbon and Climate Law Review, 4(1), 13-29.

Vogel, D. (2005). The Market for Virtue: The Potential and Limits of Corporate Social Responsibility. Washington, DC: Brookings Institution Press.

Wang, B. (2010). Can CDM bring technology transfer to China?-An empirical study of technology transfer in China's CDM projects. Energy Policy, 38, 2572-2585.

World Bank (2008a). Global Economic Prospects: Technology Diffusion in the Developing World, Washington, DC: World Bank. Retrieved from: http:// 
siteresources.worldbank.org/INTGEP2008/Resources/complete-report. pdf.

World Bank (2008b). International Trade and Climate Change: Economic, Legal and Institutional Perspectives. Washington, DC: World Bank.

World Bank (2010). World Development Report 2010: Development and Climate Change. Washington, DC: World Bank.

World Business Council for Sustainable Development. (2014). Eco-Patent Commons. Retrieved from: http://www.wbcsd.org/work-program/ capacity-building/eco-patent-commons.aspx.

World Intellectual Property Organization (WIPO) (2013). World Intellectual Property Indicators 2013. Geneva: WIPO. Retrieved from: http://www. wipo.int/ipstats/en/wipi/

World Trade Organization (WTO) (2014). Eliminating Trade Barriers on Environmental Goods and Services. Retrieved from: http://www.wto. org/english/tratop_e/envir_e/envir_neg_serv_e.htm

\section{Abstrakt (in Polish)}

Innowacja to proces z natury ryzykowny i niepewny. Wiele wyzwań zwiqzanych z innowacjami dotyczy również czystych technologii. Rozwój technologii środowiskowych jest ponadto utrudniony ze względu na specyfikę wiedzy, efekty zewnętrzne i niepewność. Niniejsza analiza koncentruje się na przegladzie literatury na temat roli niepewności, zaangażowania państw rozwijajqcych się, kontrowersji dotyczq̨cych praw własności intelektualnej oraz uczestników rynku i ich strategii. Praca ta rozważa także dostępne instrumenty polityki, koszty, korzyści i konsekwencje ich zastosowania. Naukowcy wciqż analizujq to kiedy, gdzie, dlaczego i jak tworzone i rozwijane sq innowacje dotyczq̨ce czystych technologii. Niezbędne jest, aby twórcy polityki rzq̨dów dqżyli do redukcji niepewność i ryzyka, stymulowali innowacje poprzez skuteczne egzekwowanie praw własności intelektualnej oraz wspierali przejrzystość rynku. Kwestie te będq odgywać coraz większq rolę w przyszłości, stajqc się przedmiotem dalszych badań i analiz naukowych. Konsumenci, twórcy polityki rzqdowej oraz innowatorzy mogliby odnieść korzyści z lepszego zrozumienia procesu zmian technologicznych, zwiqzanych z rozwojem, dyfuzjq i finansowaniem czystych technologii.

Słowa kluczowe: czyste technologie, innowacje środowiskowe, polityka innowacyjna, bariery innowacji, kraje rozwijajqce się.

\section{Biographical note}

Dr. Kristina M. Lybecker is the Gerald R. Schlessman Professor of Economics and Associate Chair of the Department of Economics and Business at Colorado College in Colorado Springs, CO. She received her Ph.D. in Economics in 2000 from the University of California, Berkeley. Kristina's research analyzes the difficulties of strengthening intellectual property rights protection in developing countries, specifically in the context of the pharmaceutical and environmental technology industries. Recent publications have also 
addressed alternatives to the existing patent system, the balance between pharmaceutical patent protection and access to essential medicines, and the markets for jointly produced goods such as blood and blood products. Kristina has testified in more than a dozen states on the economics of pharmaceutical counterfeiting. She has also worked with US Food and Drug Administration, Reconnaissance International, PhRMA, the National Peace Foundation, the OECD, the Fraser Institute, and the World Bank, on issues of innovation, international trade, and corruption. 